\title{
Sub-acute thyroiditis and hepatitis in a case of infectious mononucleosis
}

\author{
J. S. FENNELL \\ L.R.C.P.S.I., M.R.C.P.I.
}

\author{
G. H. TOMKIN \\ M.D., F.R.C.P.I.
}

The Adelaide Hospital, Dublin

\begin{abstract}
Summary
A viral aetiology for sub-acute (de Quervain's) thyroiditis has long been postulated although proof has been elusive. Infectious mononucleosis has been associated with sub-acute thyroiditis in only two papers, and histological evidence of sub-acute thyroiditis was lacking in both. A case of sub-acute thyroiditis, confirmed by histology, occurring in a patient with infectious mononucleosis is now reported.
\end{abstract}

\section{Case report}

A 36-year-old married man, who worked as a financier, presented to his general practitioner complaining of discomfort on swallowing of a few days' duration. On examination he was noted to have a non-tender swelling on the right side of his neck, which was thought to be thyroidal in origin. Initial blood tests were as follows: haemoglobin, $14.4 \mathrm{~g} / \mathrm{dl}$; white cell count (WBC), $7.6 \times 10^{9} / 1\left(2.37 \times 10^{9} / 1\right.$ lymphocytes), atypical lymphocytes noted on the blood film; erythrocyte sedimentation rate (ESR), $88 \mathrm{~mm} / \mathrm{hr}$ (Westergren); the Monospot test was negative.

Over the next two weeks he complained of increasing malaise, with anorexia and weight loss. He had a fever, and had himself noted his temperature to be $39^{\circ} \mathrm{C}$ on several occasions. He was admitted to hospital where the swelling was now noted to fill the right supra-clavicular fossa. At this time the following investigations were done: WBC, normal, atypical lymphocytes again noted on blood film; ESR, $116 \mathrm{~mm}$. Liver function tests: bilirubin, $10 \cdot 3$ $\mu \mathrm{mol} / 1$ (0.6 mg/dl); alkaline phosphatase, 252 i.u. $/ \mathrm{l}$; aspartate transaminase (SGPT), 49 i.u./1; serum thyroxine (T4), $133 \mathrm{nmol} / 1(10 \cdot 2 \mu \mathrm{g} / \mathrm{dl})$; thyroidstimulating hormone (TSH), $6.4 \mu \mathrm{u} . / \mathrm{ml}$. Thyroid antibodies were negative, and immunoglobulins showed a slight rise in the IgM fraction. Viral studies were negative. Repeat Monospot test was positive. Epstein-Barr virus (EBV) IgG antibody was present at a titre $1: 128$, but no rise was found.

This case was presented at a meeting of the Royal Academy of Medicine in Ireland, on 14th February, 1977.
One week after admission the thyroid gland was surgically explored to rule out thyroid carcinoma. At operation the gland was diffusely inflamed, and white in appearance. A biopsy was taken. Histology showed sub-acute thyroiditis (Fig. 1). A diagnosis of infectious mononucleosis with associated sub-acute thyroiditis and hepatitis was made. He was discharged several days later on no specific treatment, at which time his haemoglobin had dropped to $10.9 \mathrm{~g} / \mathrm{dl}$, and ESR was still markedly raised at $120 \mathrm{~mm}$.

When reviewed several weeks later his T4 had fallen to $33.5 \mathrm{nmol} / \mathrm{l}(2.6 \mu \mathrm{g} \%)$ and TSH was raised at $28 \mu \mathrm{u} . / \mathrm{ml}$, indicating hypothyroidism. However, this was only transient, and he had regained normal thyroid function in 4 months.

\section{Discussion}

Sub-acute thyroiditis has been associated with several viral infections, including mumps, measles, influenza, Coxsackie virus, and adenoviruses. However Greene (1971) reported that all attempts, except that by Eylan, Zmucky and Sheba (1957), to culture viruses or demonstrate viral inclusion bodies in thyroid tissue have failed. Sub-acute thyroiditis has also been associated with infectious mononucleosis in two papers (Mosonyi and Rusvai, 1961; Hintze, Fortelius and Railo, 1964) but histological evidence was lacking in both. The authors believe that this is the first report of sub-acute thyroiditis, which has been confirmed by histology, occurring in a patient with infectious mononucleosis. Infectious mononucleosis was confirmed by the presence of atypical lymphocytes in the peripheral blood smear, an EBV IgG antibody titre of $1: 128$, and a positive Monospot test. Twelve months later the authors looked for EBV IgM antibody in stored specimens of serum, but were unsuccessful. This may have been because $\operatorname{IgM}$ is unstable when stored, or because these serum specimens were taken late in the illness, over 2 weeks after the onset of symptoms, when EBV IgM may have disappeared (Edwards and 


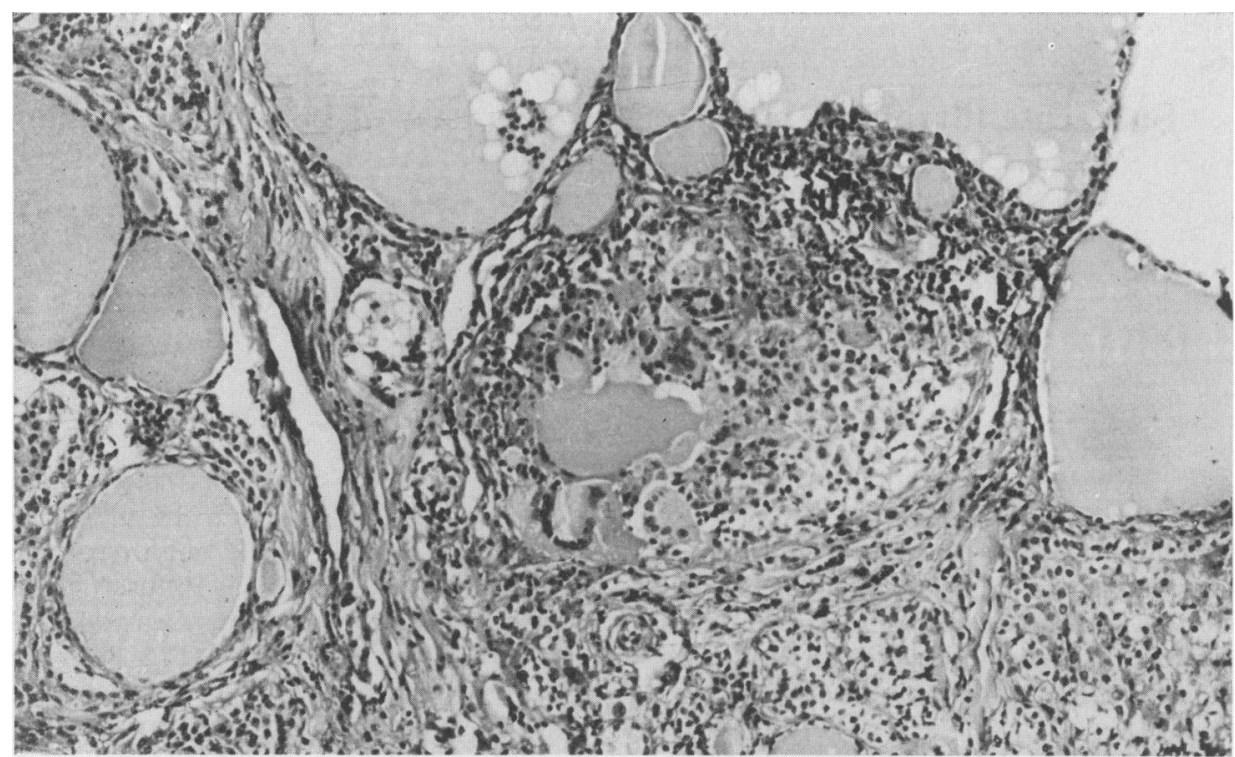

FIG. 1. Thyroid gland biopsy showing destruction of a follicle (centre) surrounded by macrophages and multinucleate giant cells. Photomicrogrpah $\mathrm{HE}, \times 54$.

McSwiggan, 1974). Sub-clinical hepatitis was detected on routine screening of liver function.

The authors feel that this report is further evidence that viruses are involved in the pathogenesis of subacute thyroiditis.

\section{References}

Edwards, J. \& McSwiggan, D. (1974) Studies on the diagnostic value of an immunofluorescence test for EB virus-specific IgM. Journal of Clinical Pathology, 27, 647.
Eylan, E., Zmucky, R. \& Sheba, C. (1957) Mumps virus and sub-acute thyroiditis. Evidence of a casual association. Lancet, i, 1062.

Greene, J.N. (1971) Sub-acute thyroiditis. American Journal of Medicine, 51, 97.

Hintze, G., Fortelius, P. \& Railo, J. (1964) Epidemic thyroiditis. Acta endocrinologica, 45, 381.

Mosonyi, L. \& RusvaI, A. (1961) Subakute thyreoiditis als Komplikation der infektinosen Mononukleose. Zeitschrift für die gesamte innere Medizin und ihre Grenzgebiete, 16, 798. 